\title{
Proteomics Analysis Reveals Altered Nutrients in the Whey Proteins of Dairy Cow Milk with Different Thermal Treatments
}

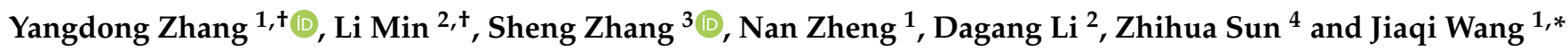 \\ 1 State Key Laboratory of Animal Nutrition, Institute of Animal Science, Chinese Academy of Agricultural \\ Sciences, Beijing 100193, China; zhangyangdong@caas.cn (Y.Z.); zhengnan_1980@126.com (N.Z.) \\ 2 Institute of Animal Science, Guangdong Academy of Agricultural Sciences, State Key Laboratory of Livestock \\ and Poultry Breeding, Key Laboratory of Animal Nutrition and Feed Science in South China, Ministry of \\ Agriculture and Rural Affairs, Guangdong Public Laboratory of Animal Breeding and Nutrition, \\ Guangzhou 510640, China; minli@gdaas.cn (L.M.); lidagang@gdaas.cn (D.L.) \\ 3 Proteomics and Metabolomics Facility, Institute of Biotechnology, Cornell University, Ithaca, NY 14853, USA \\ sz14@cornell.edu \\ 4 National Animal Husbandry Service, Beijing 100125, China; goodluck_szh@163.com \\ * Correspondence: jiaqiwang@vip.163.com; Tel.: +86-10-6281-6069; Fax: +86-10-6289-7587 \\ + Yangdong Zhang and Li Min contributed equally to this paper.
}

check for

updates

Citation: Zhang, Y.; Min, L.; Zhang, S.; Zheng, N.; Li, D.; Sun, Z.; Wang, J. Proteomics Analysis Reveals Altered Nutrients in the Whey Proteins of Dairy Cow Milk with Different Thermal Treatments. Molecules 2021, 26, 4628. https://doi.org/10.3390/ molecules 26154628

Academic Editors: Aaron T. Wright and Maksymilian Chruszcz

Received: 11 May 2021

Accepted: 21 July 2021

Published: 30 July 2021

Publisher's Note: MDPI stays neutral with regard to jurisdictional claims in published maps and institutional affiliations.

Copyright: (c) 2021 by the authors. Licensee MDPI, Basel, Switzerland. This article is an open access article distributed under the terms and conditions of the Creative Commons Attribution (CC BY) license (https:/ / creativecommons.org/licenses/by/ $4.0 /)$.

\begin{abstract}
Thermal treatments of milk induce changes in the properties of milk whey proteins. The aim of this study was to investigate the specific changes related to nutrients in the whey proteins of dairy cow milk after pasteurization at $85^{\circ} \mathrm{C}$ for $15 \mathrm{~s}$ or ultra-high temperature (UHT) at $135^{\circ} \mathrm{C}$ for $15 \mathrm{~s}$. A total of 223 whey proteins were confidently identified and quantified by TMT-based global discovery proteomics in this study. We found that UHT thermal treatment resulted in an increased abundance of 17 proteins, which appeared to show heat insensitivity. In contrast, 15 heat-sensitive proteins were decreased in abundance after UHT thermal treatment. Some of the heat-sensitive proteins were connected with the biological immune functionality, suggesting that UHT thermal treatment results in a partial loss of immune function in the whey proteins of dairy cow milk. The information reported here will considerably expand our knowledge about the degree of heat sensitivity in the whey proteins of dairy cow milk in response to different thermal treatments and offer a knowledge-based reference to aid in choosing dairy products. It is worth noting that the whey proteins (lactoperoxidase and lactoperoxidase) in milk that were significantly decreased by high heat treatment in a previous study $\left(142^{\circ} \mathrm{C}\right)$ showed no significant difference in the present study $\left(135^{\circ} \mathrm{C}\right)$. These results may imply that an appropriately reduced heating intensity of UHT retains the immunoactive proteins to the maximum extent possible.
\end{abstract}

Keywords: whey proteins; cow milk; thermal treatments; heat sensitivity

\section{Introduction}

Milk and dairy products are valuable foods that constitute an important part of the human diet and are consumed during the whole lifespan since they are a rich source of nutrients [1]. However, owing to its high nutritional value, milk also serves as an excellent growth medium for a variety of microorganisms [2], which may threaten the consumer's health with food-borne illnesses. For the sake of food safety, typically, thermal treatments are commercially used. Pasteurization and indirect ultra-high temperature (UHT) treatment $\left(\geq 135^{\circ} \mathrm{C}\right)$ are the principal thermal treatments applied to milk in the dairy industry. During thermal treatments, a number of changes in nutrients have been widely studied, such as changes in proteins [3], lactose [4], and vitamins [5]. Notably, the effects of thermal treatments on the stability of milk proteins mainly focus on the denaturation of whey proteins [6].

Whey proteins have received widespread attention based on their wide range of biological activities, including antibacterial activity, fighting inflammatory disease, improv- 
ing immunity, lowering blood pressure and cholesterol, promoting bone repair, etc. [7]. Thermal treatments of milk induce changes in the properties of milk whey proteins, thereby influence their function [8]. Previous studies have demonstrated that thermal treatments of whey proteins prior to enzymatic hydrolysis affect the properties of the peptides and alter their downstream bio-functionalities (e.g., angiotensin-converting enzyme (ACE) inhibitory activity and ferrous chelating capabilities) $[9,10]$. Furthermore, several immuneactive proteins in milk are reduced after thermal treatments [11]. Generally, whey proteins will easily undergo conformational changes with increasing temperatures, especially during UHT treatment [12]. Hence, we evaluate UHT treatment at $135^{\circ} \mathrm{C}$ in the present study, in order to clarify the nutritional retention adopted by an appropriately reduced heating intensity of milk. The differences between UHT treated milk at $135^{\circ} \mathrm{C}$ and a higher temperature was analyzed via the comparison of our study and a previous study $\left(142{ }^{\circ} \mathrm{C}\right)$ [13].

Despite changes in the milk proteins profiles upon various thermal treatments have been extensively studied already, limited is known about the nutrient difference in lowabundance proteins from milk whey proteins with different thermal treatments and the nutritional retention by an appropriately reduced heating intensity of UHT from the perspective of proteomic analysis. Yang et al. [14] reported that 211 whey proteins (including some low-abundance proteins) were identified in five species milk using conventional shotgun proteomic techniques. Based on the analysis of differentially accumulated proteins, specific functional proteins serving as potential biomarkers in whey proteins were selected as characterization traits for a given species. Subsequently, a total of 129 bovine milk proteins quantified by proteomic study revealed the nutrient difference in milk proteins after processing via pasteurization, spray drying, and freezing [15]. In the present study, we aimed to explore the nutrient difference in the whey proteins of dairy cow milk between pasteurization (at $85^{\circ} \mathrm{C}$ for $15 \mathrm{~s}$ ) and UHT treatments (at $135^{\circ} \mathrm{C}$ for $15 \mathrm{~s}$ ), especially focusing on some low-abundance proteins using advanced proteomic techniques, in order to characterize and compare the impacts on nutrients after different thermal treatments.

\section{Results and Discussion}

\subsection{Functional Category Analysis of Identified Proteins}

In the present study, 223 proteins were identified in the whey proteins using proteomics techniques (Supplemental Table S1). All identified whey proteins were further analyzed the biological processes and molecular function using gene ontology annotations. The top 10 biological processes and molecular function of whey proteins are presented in Figure 1 . The identified whey proteins are involved predominantly in the biological process of negative regulation of endopeptidase activity, and the molecular function of protein binding. Sun et al. [16] reported that the largest portion of biological process was negative regulation of endopeptidase activity in cow milk, whereas that in goat milk was positive regulation of ERK1 and ERK2 cascade. Similar results were reported in a previous study that showed that the most frequent molecular function in cow and human milk was protein binding [17], which is different from the primary molecular function in goat milk [16]. The functional category analysis of whey proteins in milk provides information on the nutrient differences among animal species, thereby distinguishing specific mammalian milks [14]. 


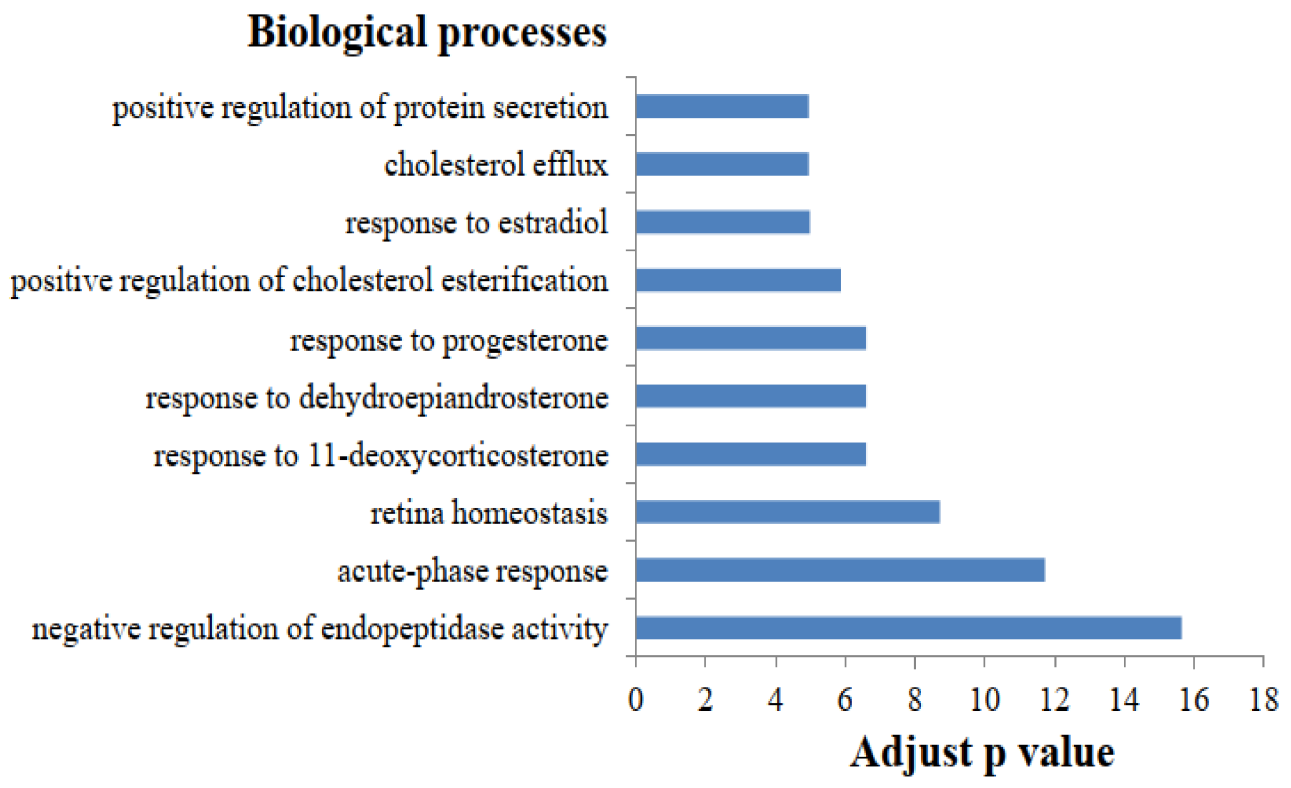

Molecular function

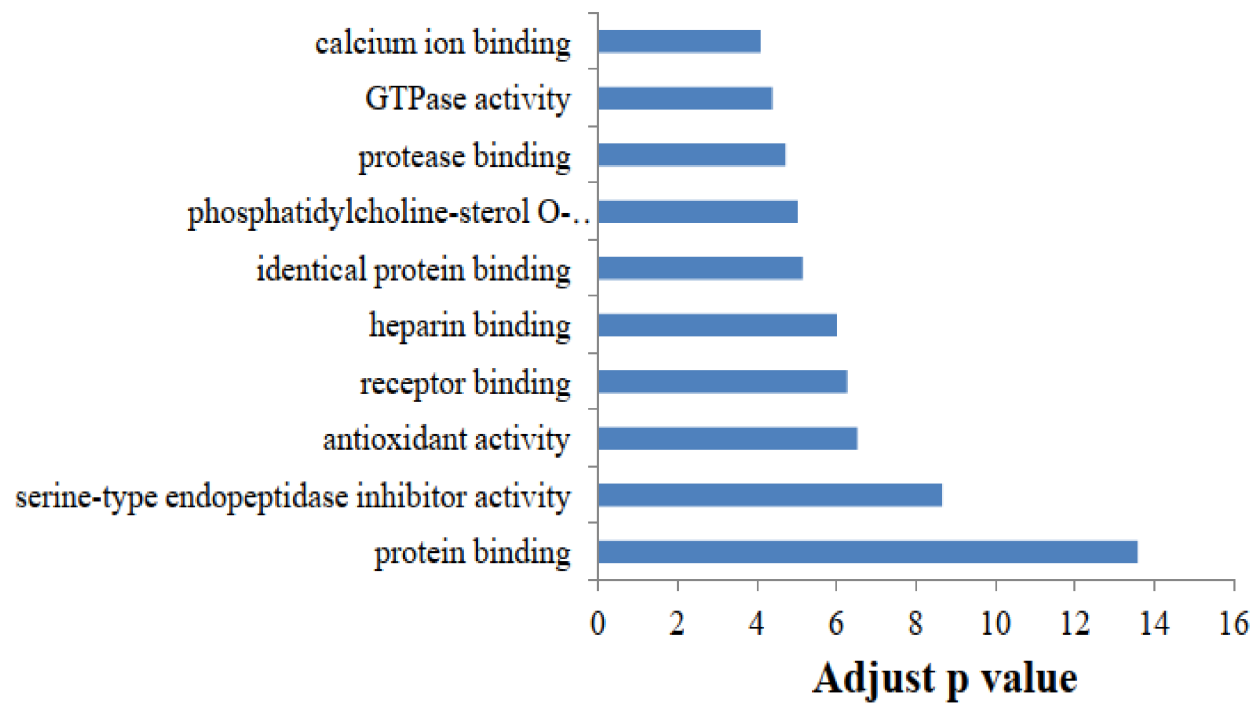

Figure 1. The top 10 biological processes and molecular function in the whey proteins of dairy cow milk (adjusted $p$ value $=-\log (\mathrm{FDR} / 100))$.

\subsection{Heat Sensitivity in Whey Proteins after Different Thermal Treatments}

The results of quantification of the whey proteins are listed in Supplemental Table S2. Of these proteins, 17 were increased in abundance and 15 were decreased after UHT thermal treatment compared with pasteurization. These 32 differentially abundant proteins are presented in Supplemental Table S3. UHT thermal treatment resulted in an increased abundance of the proteins primarily involved in antigen processing and presentation (Table 1). Yang et al. [18] demonstrated that whey proteins from both Holstein and human milk are associated with antigen processing and presentation via KEGG pathway analysis. It is well known that antigen processing and presentation play essential roles in adaptive immunity responses [19]. Notably, a few relevant studies have focused on the pathway of proteoglycans in cancer; proteoglycans seem to be important macromolecules that play a critical part in the biology of various kinds of cancer [20] and participate in the innate immune system against infections [21]. This information reminds us that heat treatments might affect the nutrient content with regard to immune function in the whey proteins. 
Table 1. Up-regulated and down-regulated proteins identified by KEGG enrichment analysis after UHT thermal treatment.

\begin{tabular}{|c|c|c|}
\hline KEGG Pathway Name & Protein Name & UHT/Pasteurization Fold Change \\
\hline \multirow{3}{*}{ Antigen processing and presentation } & Protein disulfide-isomerase A3 precursor & 1.29 \\
\hline & Cathepsin L1 precursor & 1.31 \\
\hline & Beta-2-microglobulin & 1.23 \\
\hline \multirow{3}{*}{ Lysosome } & Cathepsin L1 precursor & 1.31 \\
\hline & Prosaposin precursor & 0.82 \\
\hline & Cathepsin D precursor & 0.81 \\
\hline \multirow{3}{*}{ Phagosome } & Cathepsin L1 precursor & 1.31 \\
\hline & Ras-related C 3 botulinum toxin substrate 1 precursor & 1.21 \\
\hline & Monocyte differentiation antigen CD14 precursor & 0.78 \\
\hline \multirow{3}{*}{ Proteoglycans in cancer } & Cathepsin L1 precursor & 1.31 \\
\hline & Ras-related C 3 botulinum toxin substrate 1 precursor & 1.21 \\
\hline & Metalloproteinase inhibitor 3 precursor & 0.83 \\
\hline
\end{tabular}

Thermal treatment of milk is an essential process of milk production adopted by the dairy industry. In this process, the functionality and molecular structure of milk proteins undergo irreversible changes [22]. Thus, the nutrient difference due to the changes in whey proteins with heat treatment might be associated with differences in the amino acid sequence, spatial structure, and post-translational modifications of the proteins involved [15]. Fifteen heat-sensitive proteins identified after UHT thermal treatment are listed in Table 2. Further research is necessary to provide insights into the mechanism of heat sensitivity for these important and heat-sensitive proteins. Some of these proteins are connected with biological immune functionality, such as Ig heavy chain [23], monocyte differentiation antigen CD14 [13], and C4b-binding protein [24]. With the support of a previous study [13], we further demonstrated that UHT thermal treatment results in a partial loss of immune function in the whey proteins of dairy cow milk. Interestingly, compared with this previous study [13], the proteins significantly decreased by high heat treatment (such as lactoperoxidase and lactoperoxidase) showed no significant difference in the current study (Supplemental Table S2). The results may imply that an appropriately reduced heating intensity of UHT $\left(135^{\circ} \mathrm{C}\right.$ vs. $\left.142^{\circ} \mathrm{C}\right)$ retains immunoactive proteins to the maximum extent possible.

Table 2. Fifteen heat-sensitive proteins identified after UHT thermal treatment.

\begin{tabular}{lc}
\hline \multicolumn{1}{c}{ Protein Name } & UHT/Pasteurization Fold Change \\
\hline Alpha-S2-casein precursor & 0.70 \\
Renin receptor precursor & 0.74 \\
Solute carrier family 28 member 3 isoform X1 & 0.74 \\
Ig heavy chain Mem5-like, partial & 0.78 \\
Monocyte differentiation antigen CD14 precursor & 0.78 \\
Ras-related protein Rab-18 & 0.79 \\
Protein kinase C-binding protein NELL2 precursor & 0.81 \\
Cathepsin D precursor & 0.81 \\
Prosaposin precursor & 0.82 \\
Ras-related protein Rab-11A & 0.82 \\
C4b-binding protein alpha chain isoform X6 & 0.82 \\
Alpha-S1-casein isoform X5 & 0.82 \\
Metalloproteinase inhibitor 3 precursor & 0.83 \\
Cysteine-rich secretory protein 3 precursor & 0.83 \\
Alpha-enolase isoform X1 & 0.83 \\
\hline
\end{tabular}

\section{Materials and Methods}

\subsection{Milk Sampling and Pre-Treatment}

Milk samples, pasteurized $(n=3)$ and UHT $(n=3)$, were obtained from a commercial dairy plant. The raw milk was the same for the pasteurization process and UHT treatment in each trial, and three replicated trials were undertaken using different batches of raw 
cow milk. Raw milk was cooled to under $4{ }^{\circ} \mathrm{C}$ and stored in a raw milk reception silo, then subjected to commercial pasteurization $\left(85^{\circ} \mathrm{C}\right.$ for $15 \mathrm{~s}$, Shanghai Nanhua Transducer Manufacture Co., Ltd., Shanghai, China) and UHT ( $135^{\circ} \mathrm{C}$ for $15 \mathrm{~s}$, FLEX-NG, Tetra Pak. Pully, Sweden) within $24 \mathrm{~h}$ of milking. The weight of the first batch of raw milk was $40.6 \mathrm{t}$, which was collected from more than 1500 dairy cows, then $9.6 \mathrm{t}$ of milk was used for the pasteurization process and $31 \mathrm{t}$ milk was used for UHT treatment. The weight of the second batch of raw milk was $48.8 \mathrm{t}$, which was collected from more than 1500 dairy cows; $8.3 \mathrm{t}$ of milk was used for the pasteurization process and $40.5 \mathrm{t}$ of milk was used for UHT treatment. The weight of the third batch of raw milk was $34.6 \mathrm{t}$, which was collected from more than 1200 dairy cows; $8.9 \mathrm{t}$ of milk was used for pasteurization process, and $25.7 \mathrm{t}$ of milk was used for UHT treatment.

Milk samples $(4 \mathrm{~mL})$ were centrifuged at $4{ }^{\circ} \mathrm{C}$ and $4000 \times g$ for $20 \mathrm{~min}$, and the upper fat was manually removed to obtain skimmed milk; the procedure was repeated twice. The $\mathrm{pH}$ of each skimmed sample $(3 \mathrm{~mL})$ was adjusted to 4.6 by acetic acid under $\mathrm{pH}$ meter control, then $90 \mu \mathrm{L}$ of $3.3 \mathrm{M}$ sodium acetate was supplemented and centrifuged for $30 \mathrm{~min}$ at $14,000 \times g$; the supernatant was obtained as $\mathrm{pH} 4.6$ soluble protein samples. A $500 \mu \mathrm{L}$ aliquot of the supernatant was precipitated with $2.5 \mathrm{~mL}$ precooled $\left(-20{ }^{\circ} \mathrm{C}\right)$ phosphatecontaining $20 \mathrm{mM}$ DTT saturated acetone overnight at $-20^{\circ} \mathrm{C}$. After centrifugation to remove the supernatant at $4{ }^{\circ} \mathrm{C}$ and $15,000 \times g$ for $10 \mathrm{~min}$, the precipitate was washed with precooled $\left(-20^{\circ} \mathrm{C}\right) 80 \%$ acetone, then evaporated naturally in a ventilated kitchen.

\subsection{Proteomics Treatment and Analysis}

Protein pellets were re-suspended and denatured in $0.1 \mathrm{M}$ phosphate buffer, $\mathrm{pH} 7.0$, 5.2 M urea, 1.7 M thiourea, $0.27 \%$ SDS, $2 \%$ chaps $(w / v)$, and $0.2 \%$ TritonX-100 $(v / v)$. Further experimental operations were conducted on the basis of Thermo Scientific's TMT10plex Mass Tag Labeling Kits with a slight modification. A total of $70 \mu \mathrm{g}$ of protein in each sample was reduced, alkylated, quenched, and digested according to a previous study [25]. An aliquot of $20 \mu \mathrm{g}$ of protein in each sample was adjusted to $\mathrm{pH} 3$ using formic acid, while the remaining $50 \mu \mathrm{g}$ protein aliquot was used for digestion and TMT labeling. The samples were first reduced with $20 \mathrm{mM}$ TECP for $1 \mathrm{~h}$ at room temperature, alkylated with $20 \mathrm{mM}$ iodoacetamide for $1 \mathrm{~h}$ in the dark, and then quenched by the addition of $20 \mathrm{mM}$ Dithiothreitol (DTT). The alkylated proteins were precipitated by adding 6 volumes of ice-cold acetone and incubating at $-20^{\circ} \mathrm{C}$ overnight, then reconstituted in $50 \mu \mathrm{L}$ of $100 \mathrm{mM}$ triethylammoniumbicarbonate. Each sample was digested with $2.5 \mu \mathrm{g}$ of trypsin for $18 \mathrm{~h}$ at $35^{\circ} \mathrm{C}$. The TMT 10-plex labels were conducted as follows. The tryptic peptides from six samples of milk from the different thermal treatments (pasteurized 1, pasteurized 2, pasteurized 3, UHT 1, UHT 2, and UHT 3) were mixed with each tag, named 128C-tag, 128N-tag, 129C-tag, 129N-tag, 130C-tag, and 130N-tag, respectively. After checking label incorporation using Orbitrap Fusion (Thermo-Fisher Scientific, San Jose, CA, USA) by mixing $1 \mu \mathrm{L}$ aliquots from each sample and desalting with SCX ziptip (Millipore, Billerica, MA, USA), the six labeled samples were pooled together. The pooled TMT labeled sample was treated with $800 \mu \mathrm{L}$ of $10 \mathrm{mM} \mathrm{KH}_{2} \mathrm{PO}_{4} / 5 \% \mathrm{ACN}$ pH 3.0 and subjected to Mixed model, reversed-phase/strong cation exchange chromatography using Oasis@ MCX 1CC (30 mg) extraction cartridges. The eluted tryptic peptides were evaporated to dryness and prepared for high $\mathrm{pH}$ reverse-phase (hpRP) chromatography with a Dionex UltiMate 3000 HPLC system [25]. The LC was conducted using a gradient of $10-45 \%$ buffer B with a flow rate of $200 \mu \mathrm{L} / \mathrm{min}$. Forty-eight fractions were obtained at one-minute intervals and then pooled into six fractions at $214 \mathrm{~nm}$ via a multiple fraction concatenation strategy [26].

All of the fractions were prepared for nanoLC-MS/MS analysis by an Orbitrap Fusion mass spectrometer (Thermo-Fisher Scientific, San Jose, CA, USA) equipped with a nanospray Flex Ion Source using high energy collision dissociation (HCD), similar to a previous report [27]. The Orbitrap was coupled with an UltiMate 3000 RSLCnano. The operating steps of nanoLC-MS/MS were executed as previously described [25,28]. All data were searched under Xcalibur 2.2 operation software. 


\subsection{Data Processing, Protein Identification, and Bioinformatic Analysis}

All raw spectra from each set of TMT 10-plex experiments were analyzed using Sequest HT software within Proteome Discoverer 1.4. The bovine sequence database from NCBI was used for database searches. The default search setting used for protein identification and quantification was as described in Feng et al. [29]. Each protein identified with at least two unique peptides can be considered a confident identification. The identified proteins were analyzed by one-way ANOVA using SPSS software. When identified proteins matched with criteria $p<0.05$ plus fold change $>1.2$, they were considered differentially expressed proteins [30]. The false discovery rate (FDR) of the $p$ value was controlled by the Benjamini-Hochberg procedure. Functional category analysis of identified proteins was performed using the gene ontology (GO) annotation software (http://david.abcc. ncifcrf.gov/home.jsp, accessed on 11 March 2021). Subsequently, the Kyoto Encyclopedia of Genes and Genomes (KEGG; https:/ / www.genome.jp/kegg/ accessed on 11 March 2021) was used to analyze and classify proteomics data.

\section{Conclusions}

Thermal treatments of whey proteins prior to enzymatic hydrolysis affect the properties of the peptides and alter their downstream bio-functionalities. In the current study, 223 whey proteins from dairy cow milk after different thermal treatments were confidently identified and quantified using advanced in-depth proteomics techniques. The results showed the nutrient differences in the whey proteins of dairy cow milk between pasteurized and UHT milk, thereby yielding data on the appropriate thermal treatments to use for raw milk. Particularly, we found that UHT thermal treatment resulted in a decreased abundance of 15 heat-sensitive proteins. Some of these proteins are related to biological immune functionality, suggesting that UHT thermal treatment results in a partial loss of immune function in the whey proteins of dairy cow milk. Moreover, further research is underway to shed new light on the mechanism of heat sensitivity in these proteins, and the advantage of the appropriately reduced heating intensity of various milk products.

Supplementary Materials: Supplementary materials are available online, Table S1: The 223 whey proteins identified in dairy cow milk, Table S2: Quantification information on the whey proteins in dairy cow milk, Table S3: The differentially abundant proteins between pasteurized and UHT milk.

Author Contributions: Conceptualization, N.Z. and J.W.; methodology, S.Z.; software and formal analysis, L.M.; investigation and resources, Y.Z.; writing-original draft preparation, Y.Z. and L.M.; writing-review and editing, N.Z., D.L. and Z.S.; visualization, Y.Z. and L.M.; supervision, project administration, and funding acquisition, J.W. All authors have read and agreed to the published version of the manuscript.

Funding: This research was funded by The Agricultural Science and Technology Innovation Program (ASTIP-IAS12), Modern Agro-Industry Technology Research System of the PR China (CARS-36), The Scientific Research Project for Major Achievements of The Agricultural Science and Technology Innovation Program (CAAS-ZDXT2019004), Special fund for scientific innovation strategy-construction of high level Academy of Agriculture Science (R2017YJ-YB3006, R2018PY-QF008), and Guangdong Modern Agro-industry Technology Research System (2020KJ114). The APC was funded by ASTIP-IAS12.

Institutional Review Board Statement: Not applicable.

Informed Consent Statement: Not applicable.

Data Availability Statement: Not applicable.

Conflicts of Interest: The authors declare no conflict of interest.

Sample Availability: Samples of the compounds are available from Yangdong Zhang. 


\section{References}

1. Milkovska-Stamenova, S.; Hoffmann, R. Identification and quantification of bovine protein lactosylation sites in different milk products. J. Proteom. 2016, 134, 112-126. [CrossRef] [PubMed]

2. Claeys, W.L.; Cardoen, S.; Daube, G.; De Block, J.; Dewettinck, K.; Dierick, K.; de Zutter, L.; Huyghebaert, A.; Imberechts, H.; Thiange, P.; et al. Raw or heated cow milk consumption: Review of risks and benefits. Food Control 2013, 31, 251-262. [CrossRef]

3. Pizzano, R.; Manzo, C.; Nicolai, M.A.; Addeo, F. Occurrence of major whey proteins in the $\mathrm{pH} 4.6$ insoluble protein fraction from UHT-treated milk. J. Agric. Food Chem. 2012, 60, 8044-8050. [CrossRef] [PubMed]

4. Van Boekel, M.A.J.S. Effect of heating on Maillard reactions in milk. Food Chem. 1998, 62, 403-414. [CrossRef]

5. Cappozzo, J.C.; Koutchma, T.; Barnes, G. Chemical characterization of milk after treatment with thermal (HTST and UHT) and nonthermal (turbulent flow ultraviolet) processing technologies. J. Dairy Sci. 2015, 98, 5068-5079. [CrossRef]

6. Halabi, A.; Croguennec, T.; Bouhallab, S.; Dupont, D.; Deglaire, A. Modification of protein structures by altering the whey protein profile and heat treatment affects in vitro static digestion of model infant milk formulas. Food Funct. 2020, 11, 6933-6945. [CrossRef]

7. Krissansen, G.W. Emerging Health Properties of Whey Proteins and Their Clinical Implications. J. Am. Coll. Nutr. 2007, 26, 713S-723S. [CrossRef] [PubMed]

8. Akkerman, M.; Rauh, V.M.; Christensen, M.; Johansen, L.B.; Hammershøj, M.; Larsen, L.B. Effect of heating strategies on whey protein denaturation-Revisited by liquid chromatography quadrupole time-of-flight mass spectrometry. J. Dairy Sci. 2016, 99, 152-166. [CrossRef]

9. Adjonu, R.; Doran, G.; Torley, P.; Agboola, S. Screening of whey protein isolate hydrolysates for their dual functionality: Influence of heat pre-treatment and enzyme specificity. Food Chem. 2013, 136, 1435-1443. [CrossRef]

10. O'Loughlin, I.; Murray, B.; FitzGerald, R.; Brodkorb, A.; Kelly, P. Pilot-scale production of hydrolysates with altered biofunctionalities based on thermally-denatured whey protein isolate. Int. Dairy J. 2014, 34, 146-152. [CrossRef]

11. Laleye, L.C.; Jobe, B.; Wasesa, A.A. Comparative study on heat stability and functionality of camel and bovine milk whey proteins. J. Dairy Sci. 2008, 91, 4527-4534. [CrossRef]

12. Laiho, S.; Ercili-Cura, D.; Forssell, P.; Myllärinen, P.; Partanen, R. The effect of dynamic heat treatments of native whey protein concentrate on its dispersion characteristics. Int. Dairy J. 2015, 49, 139-147. [CrossRef]

13. Brick, T.; Ege, M.; Boeren, S.; Böck, A.; Von Mutius, E.; Vervoort, J.; Hettinga, K. Effect of Processing Intensity on Immunologically Active Bovine Milk Serum Proteins. Nutrients 2017, 9, 963. [CrossRef] [PubMed]

14. Yang, Y.; Bu, D.; Zhao, X.; Sun, P.; Wang, J.; Zhou, L. Proteomic analysis of cow, yak, buffalo, goat and camel milk whey proteins: Quantitative differential expression patterns. J. Proteome Res. 2013, 12, 1660-1667. [CrossRef] [PubMed]

15. Zhang, L.; Boeren, S.; Smits, M.; van Hooijdonk, T.; Vervoort, J.; Hettinga, K. Proteomic study on the stability of proteins in bovine, camel, and caprine milk sera after processing. Food Res. Int. 2016, 82, 104-111. [CrossRef]

16. Sun, Y.; Wang, C.; Sun, X.; Guo, M. Comparative Proteomics of Whey and Milk Fat Globule Membrane Proteins of Guanzhong Goat and Holstein Cow Mature Milk. J. Food Sci. 2019, 84, 244-253. [CrossRef] [PubMed]

17. Cao, X.; Yang, M.; Yang, N.; Liang, X.; Tao, D.; Liu, B.; Wu, J.; Yue, X. Characterization and comparison of whey N-glycoproteomes from human and bovine colostrum and mature milk. Food Chem. 2019, 276, 266-273. [CrossRef]

18. Yang, M.; Cao, X.; Wu, R.; Liu, B.; Ye, W.; Yue, X.; Wu, J. Comparative proteomic exploration of whey proteins in human and bovine colostrum and mature milk using iTRAQ-coupled LC-MS/MS. Int. J. Food Sci. Nutr. 2017, 68, 671-681. [CrossRef]

19. Saint-Sauveur, D.; Gauthier, S.F.; Boutin, Y.; Montoni, A. Immunomodulating properties of a whey protein isolate, its enzymatic digest and peptide fractions. Int. Dairy J. 2008, 18, 260-270. [CrossRef]

20. Iozzo, R.V.; Sanderson, R.D. Proteoglycans in cancer biology, tumour microenvironment and angiogenesis. J. Cell. Mol. Med. 2011, 15, 1013-1031. [CrossRef]

21. De La Torre Gomez, C.; Goreham, R.V.; Bech Serra, J.J.; Nann, T.; Kussmann, M. “Exosomics”-A Review of Biophysics, Biology and Biochemistry of Exosomes with a Focus on Human Breast Milk. Front. Genet. 2018, 9, 92. [CrossRef]

22. Grewal, M.K.; Huppertz, T.; Vasiljevic, T. FTIR fingerprinting of structural changes of milk proteins induced by heat treatment, deamidation and dephosphorylation. Food Hydrocoll. 2018, 80, 160-167. [CrossRef]

23. Hernández-Castellano, L.E.; Almeida, A.M.; Renaut, J.; Argüello, A.; Castro, N. A proteomics study of colostrum and milk from the two major small ruminant dairy breeds from the Canary Islands: A bovine milk comparison perspective. J. Dairy Res. 2016, 83, 366-374. [CrossRef] [PubMed]

24. Varghese, P.M.; Murugaiah, V.; Beirag, N.; Temperton, N.; Khan, H.A.; Alrokayan, S.H.; Al-Ahdal, M.N.; Nal, B.; Al-Mohanna, F.A.; Sim, R.B.; et al. C4b Binding Protein Acts as an Innate Immune Effector Against Influenza A Virus. Front. Immunol. 2021, 11, 585361. [CrossRef]

25. Chen, J.-W.; Scaria, J.; Mao, C.; Sobral, B.; Zhang, S.; Lawley, T.; Chang, Y.-F. Proteomic Comparison of Historic and Recently Emerged Hypervirulent Clostridium difficile Strains. J. Proteome Res. 2013, 12, 1151-1161. [CrossRef]

26. Yang, Y.; Qiang, X.; Owsiany, K.; Zhang, S.; Thannhauser, T.W.; Li, L. Evaluation of Different Multidimensional LC-MS/MS Pipelines for Isobaric Tags for Relative and Absolute Quantitation (iTRAQ)-Based Proteomic Analysis of Potato Tubers in Response to Cold Storage. J. Proteome Res. 2011, 10, 4647-4660. [CrossRef]

27. Qin, L.; Walk, T.C.; Han, P.; Chen, L.; Zhang, S.; Li, Y.; Hu, X.; Xie, L.; Yang, Y.; Liu, J.; et al. Adaption of Roots to Nitrogen Deficiency Revealed by 3D Quantification and Proteomic Analysis. Plant Physiol. 2019, 179, 329. [CrossRef] 
28. Kahl, A.; Blanco, I.; Jackman, K.; Baskar, J.; Milaganur Mohan, H.; Rodney-Sandy, R.; Zhang, S.; Iadecola, C.; Hochrainer, K. Cerebral ischemia induces the aggregation of proteins linked to neurodegenerative diseases. Sci. Rep. 2018, 8, 2701. [CrossRef] [PubMed]

29. Feng, Y.; Yin, Z.; Wu, Y.; Xu, L.; Du, H.; Wang, N.; Huang, L. LaeA Controls Virulence and Secondary Metabolism in Apple Canker Pathogen Valsa mali. Front. Microbiol. 2020, 11, 2693. [CrossRef]

30. Zhang, H.; Jiang, H.; Fan, Y.; Chen, Z.; Li, M.; Mao, Y.; Karrow, N.A.; Loor, J.J.; Moore, S.; Yang, Z. Transcriptomics and iTRAQ-Proteomics Analyses of Bovine Mammary Tissue with Streptococcus agalactiae-Induced Mastitis. J. Agric. Food Chem. 2018, 66, 11188-11196. [CrossRef] 